\title{
DNA barcodes from snake venom: a broadly applicable method for extraction of DNA from snake venoms
}

Cara Francesca Smith ${ }^{1}$, Mitchell E McGlaughlin ${ }^{1}$ \& Stephen P Mackessy ${ }^{\star, 1}$

'School of Biological Sciences, University of Northern Colorado, 501 20th Street, Greeley, CO 80639-0017, USA

BioTechniques 65: 339-345 (December 2018) 10.2144/btn-2018-0096

Keywords: c-mos $\bullet$ cyt b $\bullet$ DNA barcoding $\bullet$ ND4 $\bullet$ phylogenetics $\bullet$ snake venoms

DNA barcoding is a simple technique used to develop a large-scale system of classification that is broadly applicable across a wide variety of taxa. DNA-based analysis of snake venoms can provide a system of clas-

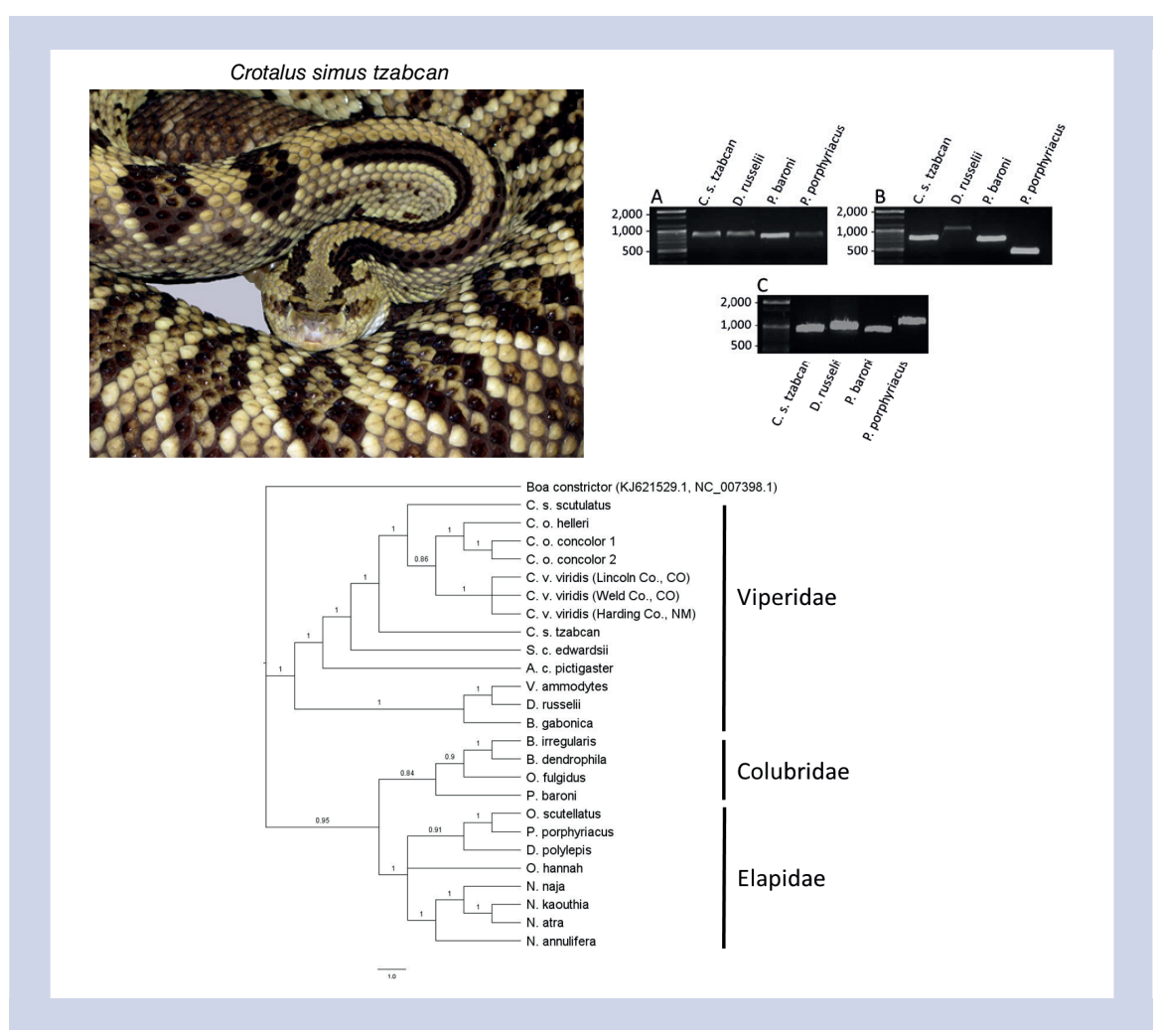

DNA barcoding provides a rapid and efficient means to determine taxonomic status of specimens using one or a few common genetic markers. This technique involves amplifying and sequencing relatively short regions of DNA (e.g., cytochrome b in animals) from a large number of organisms that display a high level of variation between species, but not within species. These reference genetic markers are used to identify species, to characterize new species, and ultimately to develop a largescale system of classification that is broadly applicable across a wide variety of taxa [1,2] . Although DNA barcoding lacks the depth of information acquired from sequencing many

sification independent of currently accepted taxonomic relationships by generating DNA barcodes specific to each venom sample. DNA purification from dried snake venoms has previously required large amounts of starting material, has resulted in low yields and inconsistent amplification, and was possible with front-fanged snakes only. Here, we present a modified DNA extraction protocol applied to venoms of both front- and rear-fanged snakes that requires significantly less starting material (1 mg) and yields sufficient amounts of DNA for successful PCR amplification of regions commonly used for DNA barcoding.

genetic regions, it compensates for this with broad applicability and high throughput potential across highly divergent species. Ultimately, the success of DNA barcoding relies on the depth and breadth of a genetic library of reference sequences.

Mitochondrial regions cytochrome C oxidase I (COI) and cytochrome b (cyt b)

\section{METHOD SUMMARY}

Modifications to a commercial DNA extraction kit (cultured cells protocol) allow purification of DNA from snake venoms for DNA-barcoding efforts. The outlined protocol uses $\sim 100 x$ less venom than previously possible and is applicable to both front- and rear-fanged venomous snakes. 
Table 1. Forward (F) and reverse ( $R$ ) primer sequence.

\begin{tabular}{|c|c|c|c|c|}
\hline Gene & Sequence $\left(5^{\prime}\right.$ to $\left.3^{\prime}\right)$ & Amplicon length (bp) & Location & Ref. \\
\hline \multirow[t]{2}{*}{ Oocyte maturation factor (c-mos) } & F-CATGGACTGGGATCAGTTATG & $500-501$ & Nuclear & [37] \\
\hline & R-CCTTGGGTGTGATTTTCTCACCT & & & \\
\hline \multirow[t]{2}{*}{ General cytochrome b (cyt b) } & F-TCAAACATCTCAACCTGATGAAA & 630 & Mitochondrial & [21] \\
\hline & R-GGCAAATAGGAAGTATCATTCTG & & & \\
\hline \multirow[t]{2}{*}{ Elapid cytochrome b } & F-TACCATGAGGACAAATATCATTCT G & 387 & Mitochondrial & [35] \\
\hline & R-CCTCCTAGTTTGTTAGGGATTGATCG & & & \\
\hline \multirow[t]{2}{*}{ NADH dehydrogenase (ND4) } & F-CACCTATGACTACCAAAAGCTCATGTAGAAGC & $651-652$ & Mitochondrial & [36] \\
\hline & R-CATTACTTTTACTTGGATTTGCACCA & & & \\
\hline
\end{tabular}

have been sequenced from thousands of animal species and are commonly used as universal markers across taxa [3-6]. Although DNA barcode sequences from these regions may only provide broad initial information, this can be used as a molecular foundation for flagging novel specimens for further analysis for purposes of species discovery, determining phylogenetic relationships and investigating population-level genetic variation [3].

Recent efforts have been made to barcode all reptiles and amphibians systematically, as only a fraction of the total herpetological diversity has been previously examined [7,8]. DNA-barcoding efforts have revealed previously unrec- ognized diversity due to the presence of cryptic species [8], particularly in areas of high herpetofaunal biodiversity [9]. For example, Pomerantz et al. [10] performed real-time DNA barcoding of reptiles in the Chocó rainforest of Ecuador with portable lab equipment to collect and analyze genetic data on rare, cryptic and endangered species, demonstrating the immediate utility of DNA barcoding efforts for assessing biodiversity. Evaluating global herpetological diversity is critical, as reptiles and amphibians represent two of the most speciose vertebrate groups on earth [8]. To further this initiative, the development of reptile- and amphibianspecific COI primers has allowed for a robust data set of over 3000 species to be compiled [8].

Aiding in the effort to create a largescale herpetofaunal database, DNA-based analysis of snake venoms allows systematic classification independent of current taxonomy by generating DNA barcodes specific to each venom sample [11]. Barcoding individual venoms provides a standardized way to classify venom samples, to confirm species identification and delineation, and to update sample identification based on taxonomic revisions. Correct identification of venom samples, especially when the source is unknown, is integral to the understanding of inter- and intra-specific venom variation.

Table 2. Qubit ${ }^{\mathrm{Tm}}$ DNA yield (ng/ml) from venom and sequencing success $(\checkmark)$ or failure $(\mathrm{X})$ at mitochondrial (ND4 and cyt b) and nuclear (c-mos) regions.

\begin{tabular}{|c|c|c|c|c|c|}
\hline & Qubit $^{\text {Tm }}$ DNA yield (ng/ml) & DNA yield (ng/mg venom) & ND4 & cyt b & c-mos \\
\hline \multicolumn{6}{|l|}{ Viperidae } \\
\hline Agkistrodon contortrix pictigaster & 27.2 & 1.13 & $\checkmark$ & $\checkmark$ & $x$ \\
\hline Bitis gabonica & 9.3 & 0.42 & $\checkmark$ & $\checkmark$ & $x$ \\
\hline Crotalus oreganus concolor & 25.2 & 0.79 & $\checkmark$ & $\checkmark$ & $\checkmark$ \\
\hline Crotalus oreganus helleri & 11.2 & 0.43 & $\checkmark$ & $\checkmark$ & $x$ \\
\hline Crotalus scutulatus scutulatus & 12 & 0.38 & $\checkmark$ & $\checkmark$ & $x$ \\
\hline Crotalus simus tzabcan & 196 & 9.8 & $\checkmark$ & $\checkmark$ & $\checkmark$ \\
\hline Crotalus viridis viridis & 80 & 2.5 & $\checkmark$ & $\checkmark$ & $x$ \\
\hline Daboia russelii & 256 & 12.8 & $\checkmark$ & $\checkmark$ & $\checkmark$ \\
\hline Sistrurus catenatus edwardsii & 10 & 0.5 & $\checkmark$ & $\checkmark$ & $x$ \\
\hline Vipera ammodytes & 60 & 2.88 & $\checkmark$ & $\checkmark$ & $\checkmark$ \\
\hline \multicolumn{6}{|l|}{ Colubridae } \\
\hline Boiga dendrophila & 88.8 & 4.11 & $\checkmark$ & $\checkmark$ & $\checkmark$ \\
\hline Boiga irregularis & 20 & 0.88 & $\checkmark$ & $\checkmark$ & $x$ \\
\hline Oxybelis fulgidus & 49.6 & 2.43 & $\checkmark$ & $\checkmark$ & $\checkmark$ \\
\hline Philodryas baroni & 544 & 26.41 & $\checkmark$ & $\checkmark$ & $\checkmark$ \\
\hline \multicolumn{6}{|l|}{ Elapidae } \\
\hline Dendroaspis polylepis & 65.5 & 3.28 & $\checkmark$ & $\checkmark$ & $\checkmark$ \\
\hline Naja annulifera & 70.4 & 3.52 & $\checkmark$ & $\checkmark$ & $\checkmark$ \\
\hline Naja atra & 3520 & 176 & $\checkmark$ & $\checkmark$ & $\checkmark$ \\
\hline Naja kaouthia & 496 & 24.8 & $\checkmark$ & $\checkmark$ & $\checkmark$ \\
\hline Naja naja & 93.6 & 4.68 & $\checkmark$ & $\checkmark$ & $\checkmark$ \\
\hline Ophiophagus hannah & 37.6 & 1.88 & $\checkmark$ & $\checkmark$ & $\checkmark$ \\
\hline Oxyuranus scutellatus & 34.8 & 1.74 & $\checkmark$ & $\checkmark$ & $x$ \\
\hline Pseudechis porphyriacus & 169 & 8.45 & $\checkmark$ & $\checkmark$ & $\checkmark$ \\
\hline
\end{tabular}


Further, because venom components vary taxonomically, geographically, ontogenetically and with dietary preference [12,13], venomic analysis alone is unlikely to provide definitive species determination of unknown samples. Recent revision or clarification of taxonomic relationships within venomous snakes has led to the invalidation of previous species' delineations, with the concomitant complication of identification of venom samples collected without voucher reference specimens of the snakes [14-25]. Because snake higher taxonomy is still disputed and warrants futher investigation, it is imperative to couple phenotypic data (in this case, venom components and protein variation) with genotypic data $[15,21]$. These shifts in taxonomic classification may negate or obfuscate previous conclusions made about the influence of phylogeny on venom variation and composition of a species, for example in the C. viridis clade $[26,27]$. Venom-based DNA barcoding provides a framework that allows for venom classifications to be updated in parallel with (yet independent of) taxonomic reassignments.

The combination of fine-level venom variation and the possibility of species misidentification, especially in light of taxonomic reorganization, can further complicate conclusions about venomic data. Such misidentification can have severe consequences with regard to snakebite treatment and management [28,29]. If these clear identifications to species are available regionally, then misapplication of antivenom therapy can be avoided.

DNA barcoding of venom samples is also useful for the confirmation of species identity of commercially available venoms, which may contain pooled venom samples from multiple species or may occasionally be entirely misidentified [11,29]. In addition, DNA-based analysis of snake venoms allowed for rapid species identification during a forensic investigation when no other information was available about a sample [30]. This analysis provided unequivocal evidence of illegal poaching, possession and smuggling of venom from the Indian cobra (Naja naja) [30]. Populations of Naja naja are in danger of extinction in part because of these illegal practices, and prevention and prosecution of these crimes is of utmost importance to ensure the protection of this species [31].
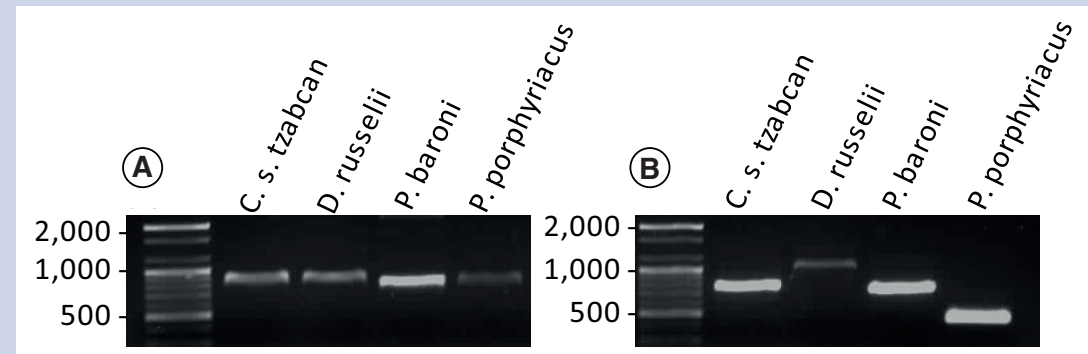

(C)

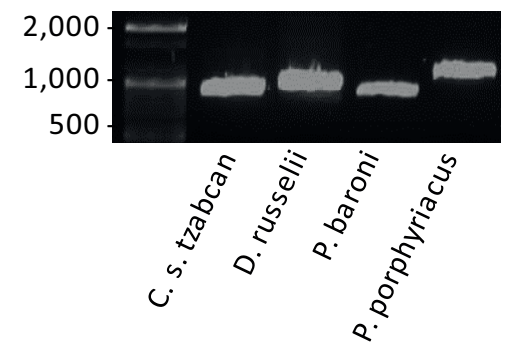

Figure 1. Example of amplified PCR products of (A) C-mos, (B) cyt b, and (C) ND4 from DNA obtained from snake venoms.

Despite its theoretical advantages, DNA purification from dried snake venom has produced low yields and inconsistent amplification, and it has yet to be investigated in a wide range of venomous snake species $[11,30]$. Further, the large quantity of starting material previously required for these analyses (100 mg) made venom DNA barcoding from rare species or species with low venom yields problematic [11,32]. Here we outline a modified method for the extraction of DNA from venom and the consistent amplification of mitochondrial markers from small amounts of venom ( 1 mg) collected from both front-fanged (families Viperidae, Elapidae and Atractaspididae) and rear-fanged (families Colubridae, Dipsadidae and others) species. This modified protocol has broad applications for genetic analysis and DNA-barcoding efforts across venomous snake species, and it allows for routine barcoding of commercial samples for unequivocal identification of species.

\section{Materials \& methods} Venom collection \& storage

All viperids (except Vipera ammodytes and Daboia russelii) and all colubrids analyzed were housed individually in the University of Northern Colorado (CO, USA) Animal Resource Facility (IACUC \#

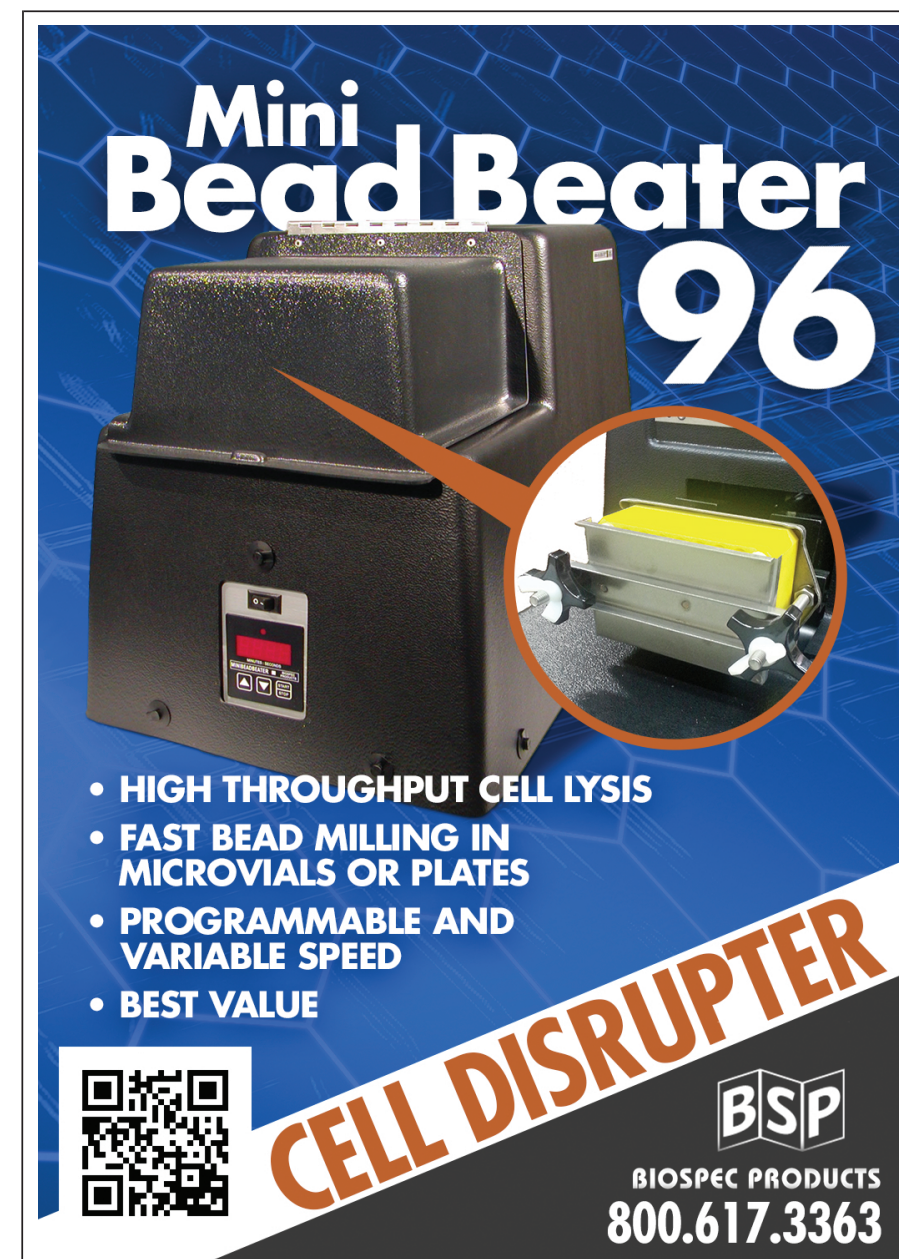


1302D-SM-S-16). Venom was extracted from viperids and colubrids as previously described [33,34]. All venoms extracted at University of Northern Colorado were centrifuged at $9500 \times \mathrm{g}$ for 5 mins, lyophilized and stored at $-20^{\circ} \mathrm{C}$.

$V$. ammodytes venom was obtained from a commercial source (Jabria B.V., Hierden, Holland) and had been air-dried. Naja naja, N. annulifera, N. kaouthia, Oxyuranus scutellatus, Dendroaspis polylepis, Ophiophagus hannah and D. russelii lyophilized venoms were donated by the Kentucky Reptile Zoo (Slade, KY). Naja atra venom (lyophilized) was acquired from Ventoxin Laboratories Incorpo-

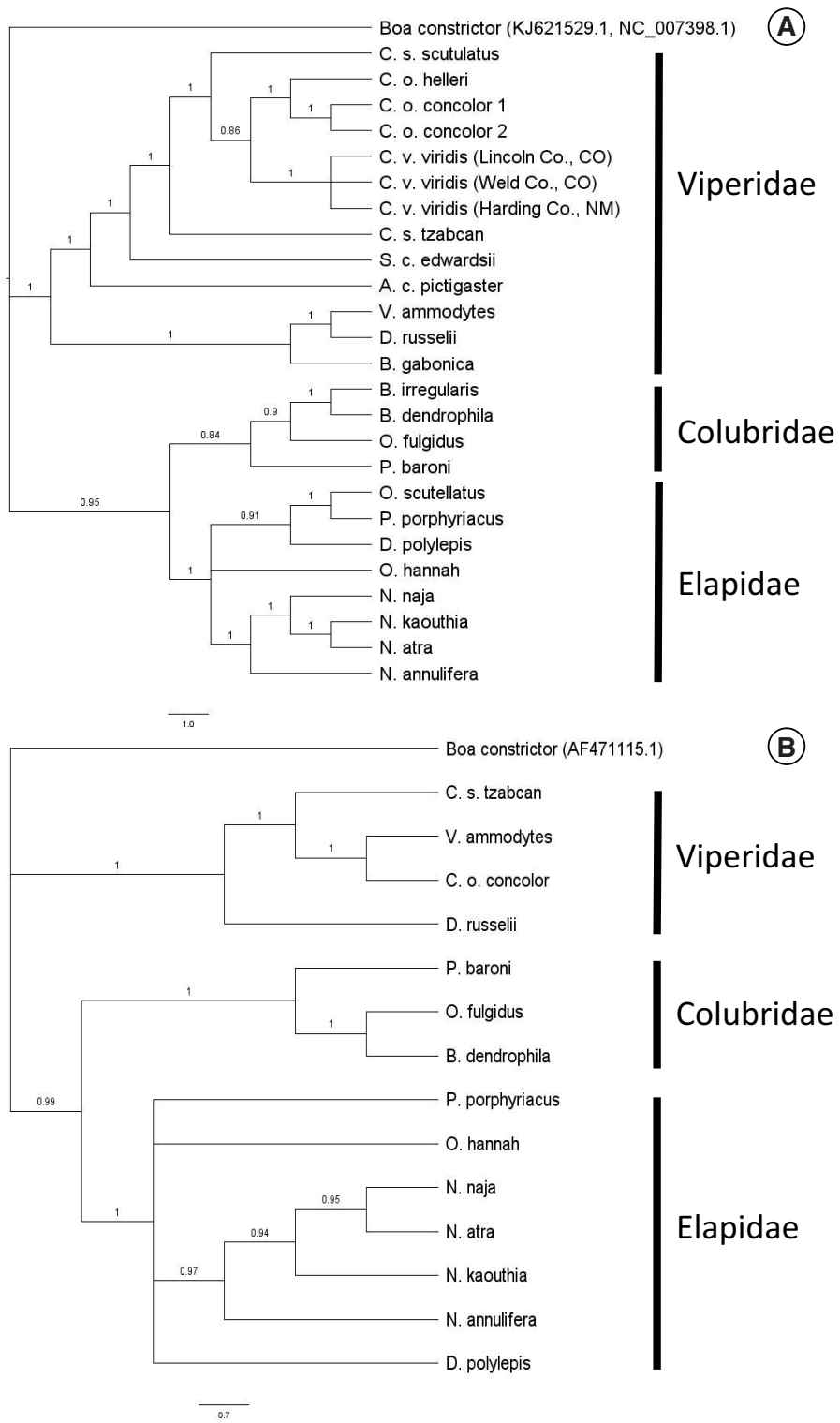

Figure 2. Phylogenetic trees with Boa constrictor as an outgroup based on concatenated sequences from (A) cyt b and ND4 and (B) c-mos region, showing posterior probabilities.
Mitochondrial \& nuclear marker amplification

Two mtDNA loci, cyt b [21,35] and ND4 [36], and one nuclear locus (C-mos) [37] were amplified from each sample (Table 1). For cyt b, primers from Kocher et al. [35] were used to amplify all elapid samples, and primers from Pook et al. [21] were used to amplify all other samples.

PCR reactions were carried out on an Eppendorf Mastercycler Gradient S (Hamburg, Germany) in total volumes of $21 \mu \mathrm{l}$, containing 2-5 $\mu$ l extracted DNA, $1 \mu \mathrm{l}(10 \mathrm{mM})$ of each primer (forward and reverse), $4 \mu$ I Promega 5x Go Flexi buffer, $1 \mu \mathrm{l} 25$ mM dNTPs, $1 \mu \mathrm{l} 25 \mathrm{mM} \mathrm{MgCl}_{2}, 0.3 \mu \mathrm{l}$ Taq polymerase (Promega Go Flexi), and nuclease-free $\mathrm{dd}_{2} \mathrm{O}$ to bring the reaction volume to $21 \mu \mathrm{l}$. A standard PCR protocol was used for amplification: 35 cycles of 1 min at $95^{\circ} \mathrm{C}$, a 1 min ramp from $50^{\circ} \mathrm{C}$ to $65^{\circ} \mathrm{C}\left(0.3^{\circ} \mathrm{C} /\right.$ second $)$, and $4 \mathrm{~min}$ at $65^{\circ} \mathrm{C} .1 \%$ agarose gels run at $125 \mathrm{~V}$ for $\sim 30$ mins were used to confirm the presence of amplified PCR products.

PCR amplification products were cleaned using ExoSAP purification: $5 \mu$ l PCR product, $0.5 \mu$ exonuclease I, and $1 \mu$ FastAP thermosensitive alkaline phosphatase. These reactions were run on an Eppendorf Mastercycler Gradient S thermal cycler at $37^{\circ} \mathrm{C}$ for $15 \mathrm{~min}$, followed by another $15 \mathrm{~min}$ at $85^{\circ} \mathrm{C}$. Purified products were then cycle-sequenced in $10 \mu$ reactions of $2 \mu$ Big Dye $5 x$ dilution buffer, $0.33 \mu$ l Big Dye III terminator, $0.8 \mu$ l cleaned PCR product, $0.5 \mu \mathrm{l}$ of forward or reverse primer, and $\mathrm{dd}_{2} \mathrm{O}$ to bring to final volume. Cycle sequencing reactions were run on an Eppendorf Mastercycler Gradient S thermal cycler: $1 \mathrm{~min}$ at $96^{\circ} \mathrm{C}$; and 30 cycles of $96^{\circ} \mathrm{C}$ for $15 \mathrm{~s}, 50^{\circ} \mathrm{C}$ for 20 $\mathrm{s}, 60^{\circ} \mathrm{C}$ for $4 \mathrm{~min}$. Samples were sent to Arizona State University's DNA Laboratory for sequencing. Sequenced sample product reads were imported into GENEIOUS (version 8.1.4; www.geneious.com) [38] and analyzed for nucleotide polymorphisms. In the case of failed amplification or failed sequencing, reaction parameters such as total amount of DNA and amount of polymerase were adjusted.

\section{Genetic analysis}

Sequences from both mitochondrial regions were concatenated to construct a single mitochondrial data set. Phylogenetic trees were constructed independently for the mitochondrial and nuclear data using 
MRBAYES [39] as run in GENEIOUS with a General Time Reversible (GTR) substitution model with a chain length of five million generations, sampling every 1000 generations for four heated chains. GENEIOUS was run with default parameters for the rest of the analysis options, including gamma rate variation with 4 gamma categories, heated chain temperature of 0.2 , and a subsampling frequency of 1000. A burn-in length of 1.5 million generations was used for each analysis.

\section{Results \& discussion \\ DNA extraction \& purification}

Successful DNA extraction from venom generally produced a low yield of DNA (Qubit $^{\text {TM }}$ average: $267.1 \mathrm{ng} / \mathrm{ml}$; range 9.3-3520 ng/ml; Table 2) that was not visible on a $1 \%$ agarose gel. However, this low DNA yield did not affect the success of mitochondrial region amplification or sequencing (Table 2). ND4 and cyt b regions successfully amplified in all species, with amplicon sequence lengths comparable to published sequences (Tables 1 \& 2) [21,30,36]. C-mos was successfully amplified in $64 \%$ of samples, with amplicon lengths equivalent to previous studies (Table 2) [37].

DNA exists in venom primarily as a result of cellular content deposition in the lumen of the venom gland following cell death. This cell debris may be ejected along with venom during prey envenomation or during venom extraction $[40,41]$. Degradative venom enzymes (nucleases, exonucleases, etc.) exist in the venom, likely in an inactivated state [41], but it is currently unknown if degradation of venom DNA occurs due to their actions. However, in addition to DNA, intact mRNA has been purified from venom [42], indicating overall stability of nucleic acids in the venom gland and in dried venom despite possible degradation via DNases and RNases found in venom.

The presence of high-quality DNA allowed species identification from a single venom sample [30] and phylogeographic analysis of mitochondrial regions [11]. DNA barcoding of venoms has been previously described using large amounts of venom (100-200 mg of lyophilized venom), but even with this amount of starting material, extractions produced very low DNA yields (<1 ng/ $\mu$; ; [11]). Although the exact mass of venom that can be extracted depends on several factors [13,34,41,43,44], for smaller species or individuals it is not possible to collect this amount from a single snake during a single extraction. Therefore, the use of over $100 \mathrm{mg}$ of starting material for genetic analysis is likely not feasible for most research efforts, but the ability to utilize 100-fold less venom (the current method) does make analysis possible.

Pook and McEwing [11] did not specify the instrument used to quantify DNA yields; however, due to potential sensitivity issues with Nanodrop [45], we utilized the highly sensitive Qubit ${ }^{\mathrm{TM}}$ fluorometer for DNA quantification. Although our DNA yield values appear significantly lower than those of Pook and McEwing [11], it is likely that Qubit ${ }^{\mathrm{TM}}$ yields are more reflective of true DNA concentration than spectrophotometric methods. Further, success at both mitochondrial regions for all samples indicates that amplification using our method can be successful even from samples with very low DNA yields (9.3 ng/ml).

Mitochondrial \& nuclear

marker amplification

Both mitochondrial regions amplified successfully in all species. In general, high-yield samples amplified successfully without further modifications to the reaction mixture. In samples with low levels of DNA template, the amount of DNA in the reaction mixture was increased if PCR failed initially. C-mos amplification was inconsistent, with a success rate of $64 \%$, and amplification success loosely correlated with DNA yield, with low-yield samples failing repeatedly despite increasing DNA concentration in the reaction mixture.

Low DNA yield did not appear to affect success of mitochondrial marker amplification. For example, low-yield Crotalus samples (C. o. helleri and C. S. scutulatus) amplified successfully for both mitochondrial regions during the first round of PCR. However, the sample with the overall lowest DNA yield (B. gabonica) amplified inconsistently (requiring additional modifications, including increasing the amount of template DNA), and the sample with the highest yield ( $P$. baroni) successfully amplified after only one round of PCR with no modifications. Interestingly, failure of amplification at the c-mos region was inconsistent, regardless of taxonomic family or DNA yield, although in general the samples with higher yields amplified more successfully. The use of c-mos primers in all squamate reptiles [46-48] indicates that the failure of c-mos to amplify consistently may instead be due to poor nuclear DNA quality or concentration, as opposed to primer nonspecificity. In fact, cells undergoing apoptosis have been observed in venom glands [40], so nuclear DNA may degrade differently than mitochondrial DNA, which typically amplified successfully and consistently.

Although c-mos amplification was successful in most larger species (e.g. D. russelii, N. atra), mitochondrial regions will likely be more reliable markers throughout venomous snake taxa, regardless of snake size or venom yield. The high number of mitochondria in venom gland cells [41], leading to higher amounts of

\section{Guiding New Generations for Decades}

Worthington is supporting
life science research and
discovery, and we have
done so for over 70 years.

Authoring technical

manuals and guides both in print and digital formats. And, we are cited in thousands of respected scientific journals across the globe.

\section{Sharing Our Enzyme Expertise}

Order your free copy of the NEW Tissue Dissociation Guide, 18th Edition.

Simply go to:

Worthington-Biochem.com/TissueDissociation/default.html 
mitochondrial DNA available for amplification versus genomic DNA, may also account for the more consistent success of mitochondrial marker amplification. Both c-mos amplification inconsistency and microsatellite amplification failure (C Smith, Unpublished Data) indicate that nuclear DNA is less abundant and more degraded than mitochondrial DNA, making nuclear markers less reliable for venom barcoding.

\section{Genetic analysis}

Phylogenetic trees built from concatenated mitochondrial sequences (Figure 2A) and the c-mos nuclear region (Figure 2B) concurred with previously established taxonomic relationships, with viperids being the most basal group and colubrids and elapids being more derived $[21,35,49]$. Successful tree building from venomderived DNA indicates that sequences obtained from venom were of high enough quality to produce useful phylogenetic information.

\section{Conclusions}

The current study describes a simple DNA extraction protocol that requires a small amount of starting material (1 mg venom) and yields sufficient amounts of DNA for consistent PCR amplification of mitochondrial and, in some cases, nuclear genes. This method also showed higher success rates of amplification at both nuclear and mitochondrial markers, in more species of different families, than previous published studies $[21,30]$. Because the amount of venom acquired from one snake is often limited, and small species may produce only several milligram of venom, this method has practical applications for DNA barcoding efforts on an individual sample scale. Additionally, venoms from rear-fanged snakes, which in general are poorly characterized and of low yield [50], can now also be barcoded, facilitating positive identifications within this speciose group of advanced snakes. Ultimately, this efficient and broadly applicable method for the barcoding of snake venoms has utility in the genetic cataloging of snakes (and likely other venom-producing taxa as well), and it has the potential to produce an abundance of genetic data from very small amounts of renewable starting material.

\section{Acknowledgments}

The authors thank Kentucky Reptile Zoo (Slade, KY, USA), Ventoxin Laboratories Incorporated (Frederick, MD, USA) and Venom Supplies Pty. Ltd (Tanunda, South Australia) for providing some of the venoms used in this study, and Brenda Jones for her assistance with DNA extractions.

\section{Data accessibility}

C-mos, cyt b and ND4 DNA sequences: Genbank accessions MH122670 MH122733. Available: 31 July 2018.

\section{Financial \& competing interests disclosure}

Funding for this research was provided by the University of Northern Colorado School of Biological Sciences. The authors have no other relevant affiliations or financial involvement with any organization or entity with a financial interest in or financial conflict with the subject matter or materials discussed in the manuscript apart from those disclosed.

No writing assistance was utilized in the production of this manuscript.

\section{Author contributions}

Research was designed by all authors, and performed by CS using reagents and samples provided by SM and MM. Analysis and interpretation of data was performed by CS. Manuscript drafts were written by CS, with revisions from SM and MM.

\section{Supplementary data}

To view the supplementary data that accompany this paper please visit the journal website at www.future-science.com/ doi/suppl/10.2144/btn-2018-0096

\section{Open access}

This article is distributed under the terms of the Creative Commons AttributionNonCommercial-NoDerivatives 4.0 Unported License. To view a copy of this license, visit http://creativecommons.org/ licenses/by-nc-nd/4.0/

\section{References}

1. Coissac E, Hollingsworth PM, Lavergne S, Taberlet P. From barcodes to genomes: extending the concept of DNA barcoding. Mol. Ecol. 25, 1423-1428 (2016).

2. Moritz C, Cicero C. DNA barcoding: promise and pitfalls. PLoS Biol. 2, e354 (2004).

3. Hajibabaei M, Singer GA, Hebert PD, Hickey DA DNA barcoding: how it complements taxonomy, molecular phylogenetics and population genetics. Trends Genet. 23, 167-172 (2007).

4. Hebert PD, Cywinska A, Ball SL. Biologica identifications through DNA barcodes. Proc. Royal Soc. London B: Biol. Sci. 270, 313-321 (2003).

5. Kerr KC, Stoeckle MY, Dove CJ, Weigt LA, Francis CM, Hebert PD. Comprehensive DNA barcode coverage of North American birds. Mol. Ecol. Resour. 7, 535-543 (2007).

6. Yang Z, Rannala B. Bayesian species identification under the multispecies coalescent provides significant improvements to DNA barcoding analyses. Mol. Ecol. 26, 3028-3036 (2017).

7. Chambers EA, Hebert PD. Assessing DNA barcodes for species identification in North American reptiles and amphibians in natural history collections. Plos One 11, e0154363 (2016).

8. Murphy RW, Crawford AJ, Bauer AM et al. Cold Code: the global initiative to DNA barcode amphibians and nonavian reptiles. Mol. Ecol. Resour. 13, 161-167 (2013).

9. Nagy ZT, Sonet G, Glaw F, Vences M. First largescale DNA barcoding assessment of reptiles in the biodiversity hotspot of Madagascar, based on newly designed COI primers. PLoS One 7 , e34506 (2012).

10. Pomerantz A, Peñafiel N, Arteaga $A$ et al. Real-time DNA barcoding in a rainforest using nanopore sequencing: opportunities for rapid biodiversity assessments and local capacity building. GigaScience 7, giy033 (2018).

11. Pook CE, McEwing R. Mitochondrial DNA sequences from dried snake venom: a DNA barcoding approach to the identification of venom samples. Toxicon 46, 711-715 (2005).

12. Chippaux JP, Williams V, White J. Snake venom variability: methods of study, results and interpretation. Toxicon 29, 1279-1303 (1991).

13. Mackessy SP, Williams K, Ashton KG. Ontogenetic variation in venom composition and diet of Crotalus oreganus concolor: a case of venom paedomorphosis? Copeia 2003, 769-782 (2003).

14. Anderson CG, Greenbaum E. Phylogeography of northern populations of the blacktailed rattlesnake (Crotalus molossus Baird and Girard, 1853), with the revalidation of $C$. ornatus Hallowell, 1854. Herpetol. Monogr. 26 19-57 (2012).

15. Ashton KG, de Queiroz A. Molecular systematics of the western rattlesnake, Crotalus viridis (Viperidae), with comments on the utility of the D-loop in phylogenetic studies of snakes. Mol. Phylogenetics Evol. 21, 176-189 (2001).

16. Castoe TA, Parkinson CL. Bayesian mixed models and the phylogeny of pit vipers (Viperidae: Serpentes). Mol. Phylogenetics Evol. 39, 91-110 (2006).

17. Castoe TA, Smith EN, Brown RM, Parkinson CL. Higher-level phylogeny of Asian and American coral snakes, their placement within the Elapidae (Squamata), and the systematic affinities of the enigmatic Asian coralsnake Hemibungarus calligaster. Zool. J. Linn. Soc. 151, 809-831 (2007). 
18. Castoe TA, Streicher JW, Meik JM et al. Thousands of microsatellite loci from the venomous coralsnake Micrurus fulvius and variability of select loci across populations and related species. Mol. Ecol. Resour. 12, 11051113 (2012).

19. Douglas ME, Schuett GW. Phylogeography of the western rattlesnake (Crotalus viridis) complex, with emphasis on the Colorado Plateau. In: Biology of the Vipers, Schuett GW, Höggren M, Douglas ME, Greene HW (Eds), Eagle Mountain Publishing, UT, USA 11-50 (2002).

20. Meik JM, Streicher JW, Lawing AM, FloresVillela O, Fujita MK. Limitations of climatic data for inferring species boundaries: insights from speckled rattlesnakes. PloS One 10, e0131435 (2015).

21. Pook CE, Wüster W, Thorpe RS. Historical biogeography of the western rattlesnake (Serpentes: Viperidae: Crotalus viridis), inferred from mitochondrial DNA sequence information. Mol. Phylogenetics Evol. 15, 269-282 (2000).

22. Reyes-Velasco J, Meik JM, Smith EN, Castoe TA. Phylogenetic relationships of the enigmatic longtailed rattlesnakes (Crotalus ericsmithi, C. lannomi, and C. stejnegeri). Mol. Phylogenetics Evol. 69, 524-534 (2013).

23. Slowinski JB, Keogh JS. Phylogenetic relationships of elapid snakes based on cytochrome b mtDNA sequences. Mol. Phylogenetics Evol. 15, 157-164 (2000).

24. Davis MA, Douglas MR, Collyer ML, Douglas ME. Deconstructing a species-complex: geometric morphometric and molecular analyses define species in the Western Rattlesnake (Crotalus viridis). PloS One 11, e0146166 (2016).

25. Wüster W, Crookes S, Ineich I, Mané Y, Pook CE, Trape JF, Broadley DG. The phylogeny of cobras inferred from mitochondrial DNA sequences: evolution of venom spitting and the phylogeography of the African spitting cobras (Serpentes: Elapidae: Naja nigricollis complex). Mol. Phylogenetics Evol. 45, 437-453 (2007).

26. Foote R, MacMahon JA. Electrophoretic studies of rattlesnake (Crotalus \& Sistrurus) venom: taxonomic implications. Comp. Biochem. Physiol. B: Comp. Biochem. 57, 235-241 (1977).

27. Mackessy SP. Evolutionary trends in venom composition in the western rattlesnakes (Crotalus viridis sensu lato): toxicity vs. tenderizers. Toxicon 55, 1463-1474 (2010).

28. Warrell DA. Unscrupulous marketing of snake bite antivenoms in Africa and Papua New Guinea: choosing the right product - 'What's in a name?'. Trans. R. Soc. Trop. Med. Hyg. 102, 397-399 (2008)

29. Wüster W, McCarthy CJ. Venomous snake systematics: implications for snake bite treatment and toxinology. In: Envenomings and their treatments. Bon C, Goyffon M (Eds), Foundation Mérieux, Lyon, France 13-23 (1996).

30. Singh CS, Gaur A, Sreenivas A, Singh L. Species identification from dried snake venom. J. Forensic Sci. 57, 826-828 (2012).

31. Dubey B, Meganathan PR, Haque I. DNA minibarcoding: an approach for forensic identification of some endangered Indian snake species. Forensic Sci. Int. Genet. 5, 181-184 (2011).

32. Powell RL, Reyes SR, Lannutti DI. Molecular barcoding, DNA from snake venom, and toxinological research: considerations and concerns. Toxicon 48, 1095-1097 (2006).
33. Hill RE, Mackessy SP. Venom yields from several species of colubrid snakes and differential effects of ketamine. Toxicon 35, 671-678 (1997).

34. Mackessy SP. Venom ontogeny in the Pacific rattlesnakes Crotalus viridis helleri and C. v. oreganus. Copeia 92-101 (1988).

35. Kocher TD, Thomas WK, Meyer A et al. Dynamics of mitochondrial DNA evolution in animals: amplification and sequencing with conserved primers. Proc. Natl Acad. Sci. 86, 6196-6200 (1989).

36. Arevalo E, Davis SK, Sites JW Jr. Mitochondrial DNA sequence divergence and phylogenetic relationships among eight chromosome races of the Sceloporus grammicus complex (Phrynosomatidae) in central Mexico. Syst. Biol. 43, 387-418 (1994).

37. Lawson R, Slowinski JB, Crother BI, Burbrink FT. Phylogeny of the Colubroidea (Serpentes): new evidence from mitochondrial and nuclear genes. Mol. Phylogenetics Evol. 37, 581-601 (2005).

38. Kearse M, Moir R, Wilson A et al. Geneious Basic: an integrated and extendable desktop software platform for the organization and analysis of sequence data. Bioinformatics 28, 1647-1649 (2012)

39. Ronquist F, Teslenko M, Van Der Mark $P$ et al. MrBayes 3.2: efficient Bayesian phylogenetic inference and model choice across a large model space. Syst. Biol. 61, 539-542 (2012)

40. Mackessy SP. Morphology and ultrastructure of the venom glands of the northern Pacific rattlesnake Crotalus viridis oreganus. J. Morphol. 208, 109-128 (1991).

41. Mackessy SP, Baxter LM. Bioweapons synthesis and storage: the venom gland of front-fanged snakes. Zool. Anz. 245, 147-159 (2006).

42. Modahl CM, Mackessy SP. Full-length venom protein cDNA sequences from venom-derived mRNA: exploring compositional variation and adaptive multigene evolution. PLOS Negl. Trop. Dis. 10, e0004587 (2016).

43. Klauber LM. Rattlesnakes: their habits, life histories and influences on mankind. University of California Press, CA, USA (1956).

44. Mackessy SP. Fractionation of red diamond rattlesnake (Crotalus ruber ruber) venom: protease, phosphodiesterase, L-amino acid oxidase activities and effects of metal ions and inhibitors on protease activity. Toxicon 23, 337-340 (1985).

45. Kapp JR, Diss T, Spicer J et al. Variation in pre-PCR processing of FFPE samples leads to discrepancies in $B R A F$ and EGFR mutation detection: a diagnostic RING trial. J. Clin. Pathol. 68, 111118 (2015).

46. Graybeal A. Evaluating the phylogenetic utility of genes: a search for genes informative about deep divergences among vertebrates. Syst. Biol. 43, 174-193 (1994).
47. Saint KM, Austin CC, Donnellan SC, Hutchinson MN. C-mos, a nuclear marker useful for squamate phylogenetic analysis. Mol. Phylogenetics Evol. 10, 259-263 (1998).

48. Slowinski JB, Lawson R. Snake phylogeny: evidence from nuclear and mitochondrial genes. Mol. Phylogenetics Evol. 24, 194-202 (2002).

49. Vidal N, Delmas AS, David P, Cruaud C, Couloux A, Hedges SB. The phylogeny and classification of caenophidian snakes inferred from seven nuclear protein-coding genes. C. R. Biol. 330, 182-187 (2007).

50. Mackessy SP, Saviola AJ. Understanding biological roles of venoms among the Caenophidia: the importance of rear-fanged snakes. Integr. Comp. Biol. 56, 1004-1021 (2016).

First draft submitted: 2 July 2018; Accepted for publication: 29 August 2018

Address correspondence to: Stephen P Mackessy, School of Biological Sciences, University of Northern Colorado, 501 20th Street, Greeley, CO 80639 0017, USA; Fax: +1 970351 2335; E-mail: stephen. mackessy@unco.edu

\section{To purchase reprints of this article contact:} s.cavana@future-science.com

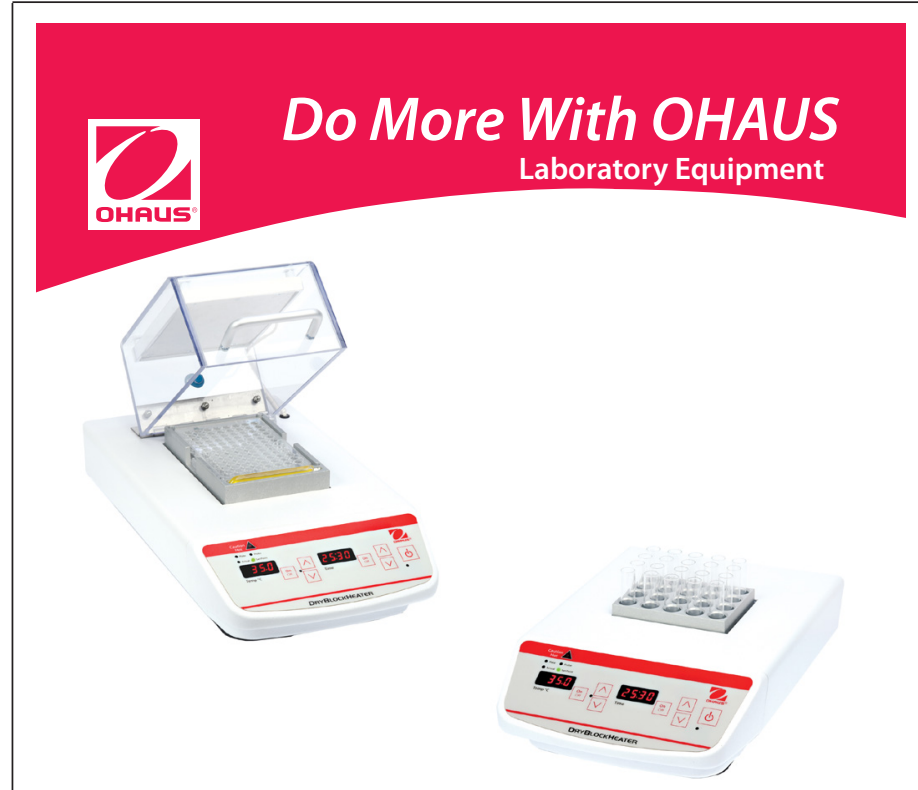

\section{Heat It Up With OHAUS}

A wide variety of Dry Block Heaters gives you the versatility you need to heat up the lab! Offering heated lid models, multiple 6-block capacity options, and over 40 accessory blocks for various sample sizes, the OHAUS line of Dry Block Heaters is prepared to handle all of your low- and high-throughput needs. 